
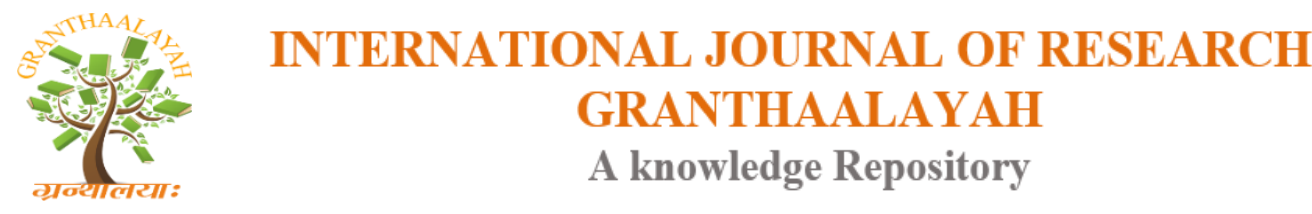

Science

\title{
STRENGTHENING HEALTH RESEARCH FOR CLIMATE CHANGE IN AFRICA
}

\author{
Andre Yitambe ${ }^{1}$, Peterson Njogu Warutere ${ }^{2}$, Kenneth Rucha Kibarraa ${ }^{3}$ \\ ${ }^{1}$ Department of Health Management and Informatics, School of Public Health, Kenyatta \\ University GPO. 00100 - 438444, Nairobi - Kenya \\ 2 Department of Environmental health, School of Public Health, Kenyatta University GPO. \\ 00100 - 438444, Nairobi - Kenya \\ ${ }^{3}$ Department of Health Management and Informatics, School of Public Health, Kenyatta \\ University GPO. 00100 - 438444, Nairobi - Kenya
}

\begin{abstract}
Despite the complexity of climate change and health research, studies conducted are still remaining non-interdisciplinary and non -multidisciplinary. A number of literatures has demonstrated the complexity for carrying research on climate change from social sciences, climate sciences to public health sciences. Social scientists look at the climate change as a social constructedness when climate scientists look at the climate change in term of terrestrial, oceanographic, and atmospheric change due to carbon dioxide emission, greenhouse emission, and ozone depletion. Health research studies have demonstrated the impact of climate change on health In Africa, Middle Income Countries as well as in Advanced Industrialized countries. Drawn on ethno-monographic studies, desk-based studies, secondary data and review of literatures relative to climate change and health, this paper examines the impact of climate change in Africa. The findings reveal three impacts of climate change: direct effects, indirect effects and postulated effects. The findings inform Disaster Risk Reduction Policy Makers on mitigation measure and adaption.
\end{abstract}

Keywords: Adaption; Climate Change; Disaster Risk Reduction; Health Research; Impact; Mitigation.

Cite This Article: Andre Yitambe, Peterson Njogu Warutere, and Kenneth Rucha Kibarraa. (2018). "STRENGTHENING HEALTH RESEARCH FOR CLIMATE CHANGE IN AFRICA." International Journal of Research - Granthaalayah, 6(4), 121-130. https://doi.org/10.29121/granthaalayah.v6.i4.2018.1622.

\section{Introduction}

\section{Background}

In June 2007, international headlines were taken up with the story that China's annual carbon oxides $\left(\mathrm{CO}, \mathrm{CO}_{2}\right)$ emission had for the first time surpassed those of USA. A small decline in US emissions, associated with downturn in economic growth, combining with with continuing 
expansion China's use of coal-burning power station and a further leap power forward in its cement production led the Netherlands Environmental Assessment Agency (Milieu - en Natuurplanbureau, MNP) to estimate in 2006 China's emission had exceeded those of US by around 8 percent. The surprise was not that China's $\mathrm{CO}_{2}$ emission should one day overtake those of US, but such an eventuality had been predicted for several years. What was starting according to the $M N P$ was that China had risen to world leading emitter so quickly and by such a significant margin. Climate analyst feared that this rapid rise in emission would mean that forecast climate changes might come more quickly than had been anticipated or even that atmospheric $\mathrm{CO}_{2}$ levels might reach new, higher peak before atmospheric greenhouse gas levels could be stabilized; in turn this would leave policy makers less time than had been assumed to respond to global warming and to reach international agreements. (Yearley S., 2009).

Yearley argues that the business of predicting greenhouse emissions, climate futures and policy responses is critically dependent of social variables such as the choice of technology, regional development policies, consumers' behavior and the performance of the economy. The scientific models of the climate, oceans and atmospheric operated under the scientist associated with the IPCC (Intergovernmental Panel on Climate Change). The IPCC was established by the World Meteorological Organization and United Nations Environmental Programmes in 1988 and placed under the auspice of the United Nations in 1999. His mandate is to assess and evaluate climate change trends. The assessment reports periodically summarize and evaluate the state of scientific understanding and the IPCC findings have been unanimously accepted by representatives of 150 member nations and endorsed by the leading national academic of science in the world. (IPCC, 1996; IPCC, 2000; IPCC, 2001; IPCC2007). These assessment reports pay little attention to health impacts of climate change.

New evidence indicates that anthropogenic sources contribute to climate change and accelerate the ongoing process of natural global warming. Extensive deforestation of large surface areas of the earth has resulted in significant change in the water and radiation balance in Africa and in the planet. Other adverse anthropogenic impacts on climate include use of biofuel, land use, pollution due to urbanization and industrialization and increases in the use of fossil fuels. The release of gases such as carbon oxides $\left(\mathrm{CO}, \mathrm{CO}_{2}\right)$, nitrogen oxides $(\mathrm{NO})$, methane $\left(\mathrm{CH}_{4}\right)$ among others Chlorofluoro-carbons (CFCs), sulfur dioxide ( $\left.\mathrm{SO}_{2}\right)$ and Persistent Organic Pollutants (POPs) contribute significantly to warming process and change in atmospheric composition. An increase in anthropogenic input of greenhouse gases has been suspected to contribute to the global temperature increase, to the associated sea level rise and the higher frequency and intensity of weather related disasters. (Van der Sluijs, Jeroen 1997; Stern N. 2007; Stackley S. et al. 1999; Pearce D. et al. 1996; Demeriit D. 2006). Natural processes in combination with anthropogenic processes may also contribute to climate change (Hyogo Framework for Action, 2003). Climate change is expected to cause 250000 additional deaths per year from malaria, diarrhea and heat stress (IPCC, 2014). African countries with weal health infrastructure will be the least able to cope with.

\section{Climate Change, Human Health, and Health Research}

The African continent is quite passive on research dealing with health impact of climate change. This can be explained by the lack of integration of health research in the health system. Health Research is concerned with investment in health and priority setting in view to improve human 
health. The concept of Health of Research entails the concept of health sustainability. Health must not be considered separately. It is always connected to poverty, development, food safety, social justice and disasters. Climate change is arguably the most important underlying disaster risk factors and implicated in the increase in disaster activities worldwide. Drought, desertification, flooding, environmental degradation such as deforestation, erosion, and loss of biodiversity) are all affected by climate change and have far-reaching consequences in term of food and water security in Africa.

Research on climate change and health intersects and build on other scientific and social area concerned with the earth changing environmental patterns. By identify the role of health researchers within the arena, other researchers from non-health background may be encouraged to contribute from their respective fields and collaborate for a broader understanding and better solutions. Just as health research has progressed from description of diseases, epidemiology, and risk factors to more upstream determinants of health issues. Climate change research in general and climate change health research in particular will benefit from inclusion criteria of researchers from diverse background and approaches. One of the roles of health research is to ensure that measure proposed to break out of the vicious impact circle of ill health and climate change.

\section{Statement of the Problem}

Without doubt, the climate is changing. Despite the climate change and its effects on human health in Africa, a little attention has been paid to his different impact on economy, social and human health. Health is especially affected by climate change. However many researches continue to be conducted in particular field such as: geography, economics, anthropology, political science, sociology or psychology. Health research on Climate change offers an opportunity to bring many disciplines together with emphasis on multidisciplinary and interdisciplinary research. Specifically, climate change as a disaster an author argues that we must expand our research horizons to examine conflict and slow onset of disaster events in developing countries which result in human cost (Peek L., 2006). As the members of academic hazard community develop health research agenda, we must challenge ourselves to look deep and ask the questions that have not yet been asked but are central to improving the human condition. Where are the gaps in our knowledge, theoretically, empirically, practically about health research and climate change in Africa?

\section{Objective of the Study}

A number of scientists have tried to explain climate change through General Circulation Model (GCM) and thermodynamics. Scientific evidences show the rising of temperature in Africa. This paper is not exploring the process of climate change but it examines the impact of climate change on human health in Africa.

\section{Materials and Methods}

Drawn on ethno-monographic studies, desk-based studies, secondary data and review of literatures relative to climate change and health, this paper examines the impact of climate change in Africa.

\section{Findings}


The works of the following authors: (McMihael A., Ghiteko A. et al. (2001); McMihael A. et al. (2004); Meehl Ga et al. (2004); Robert I. (2008); Terser F.C (2006); UNFCCC (2005); WHO (2007); Yasmin (2007) postulate three broad categories of health impacts to result from climate change as shown the Figure 1.

There is still uncertainty about the possible scale of global warming in the future and its likely direct and indirect effects. But atmosphere concentrations of the most important greenhouse gases (carbon oxides, halocarbons, methane and nitrous oxide) are increasing and the rate of increase for each of these has been particularly rapid since around 1950. There is evidence of an increase in the global average temperature over the last 120 years and many of the warmest years on record have been in the last 15 years. Glaciers in virtually all parts of the world are receding. These are consistent with global warming induced by greenhouse gases released by human activities, but there are uncertainties as to the extent to which the increase in global temperature is the result of human activities and the extent to which it will continue. For instance non-human-induced factors such as volcanic eruptions are also important. Some of the warming trend might be part of a natural variation that may reverse itself. There are uncertainties as to the extent to which increasing carbon dioxide concentrations in the atmosphere will be absorbed by increased plant growth or ocean sinks. But if global warming arising from human-induced release of greenhouse gases does continue, which it certainly will if no action is taken to moderate such emissions, it is likely to create very serious problems for a large number of the African's settlements (Hardoy J., Mitlin D.,Satterthwaite D. 2001). Southern Africa will be the most vulnerabke.
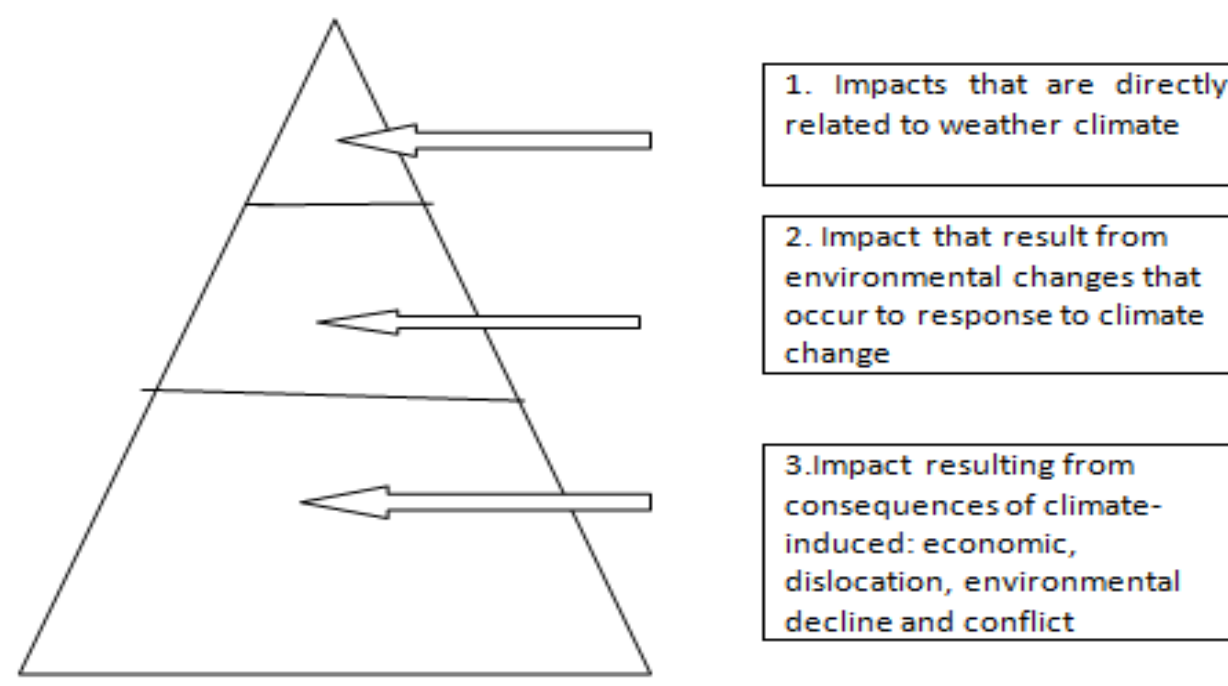

3.Impact resulting from consequences of climateinduced: economic, dislocation, environmental decline and conflict

Figure 1: Three broad categories of health impacts

Source: Adapted from McMichael et al. (2001)

Drawn on the works of McMichael and the Working Group of the Intergovernmental Panel Conference on climate Change (2001), there are three broad categories of health impacts of climate conditions: (1) Direct impact of climate change (2) Indirect impacts of climate change, and (3) Postulated effects of climate change.

\subsection{Direct Effect of Climate of Climate Change on Health}


Direct effects refer to exposure. The individual or community faces directly the impact of weather change. This can be explained by the shift of the temperature to extreme becoming a threat for human health. The direct effects of changes in temperature (including heat waves) and the changes in weather that this brings, including changes in the hydrological cycle (and thus water supplies) and altered frequency and/or intensity of extreme weather events: heat wave, global population migration and extreme temperature.

\subsection{Indirect Effects of Climate Change on Health}

Indirect Impacts result from environmental changes that occur to response to climate change The indirect effects, as the changes in temperature and the weather induce changes in (among other things) sea levels, ecological systems and air pollution levels, with these ecological changes also having significant effects on, for instance, food production. Table 1 illustrates the range of possible health impacts of climate change and also of stratospheric ozone depletion.

With regard to Africa, among the most immediate effects of climate change would be

- Higher global mean temperatures;

- Sea level rises;

- Changes in weather patterns (including those of rainfall and other forms of precipitation);

- Changes in river flow arising from increased temperature (and the melting of snow and ice) and changes in precipitation with increased risks of flooding in many cities of particular city-districts;

- Changes in evaporation rates;

- Changes in the structure of ecosystems, for instance as a result of changes in plant growth rates and favoured species and in insect populations; and

- Changes in the frequency and severity of extreme weather conditions such as storms and sea surges (Hardoy J., Mitlin D. et al.2001) as well as:

- Food and water supplies

- Droughts

- Vector-borne and air-borne diseases

- Vector-borne and water-borne diseases

\subsection{Postulated Effects of Climate Change on Health}

The scale and nature of the consequences will obviously differ depending on the city location, the characteristics of its site and the particular changes in that region in Africa (for instance) precipitation and humidity. There will also be very large differences in the capacity of city authorities and of African community -based households and enterprises to take measures to limit an increase in risk (for instance by better drainage systems and other measures to protect against flooding) and to ensure rapid and effective responses when flooding or some other disaster occurs. Sea-level rises will obviously be most disruptive to settlements on African coastal and estuarine areas and this is where a considerable proportion of the world's population lives. One estimate suggested that 60 per cent of the world's population live within 60 kilometers of a seacoast (Hardoy J., Mitlin D.,Satterthwaite D. 2001).

Table 1: Possible major types of health impact of climate change and stratospheric ozone depletion 


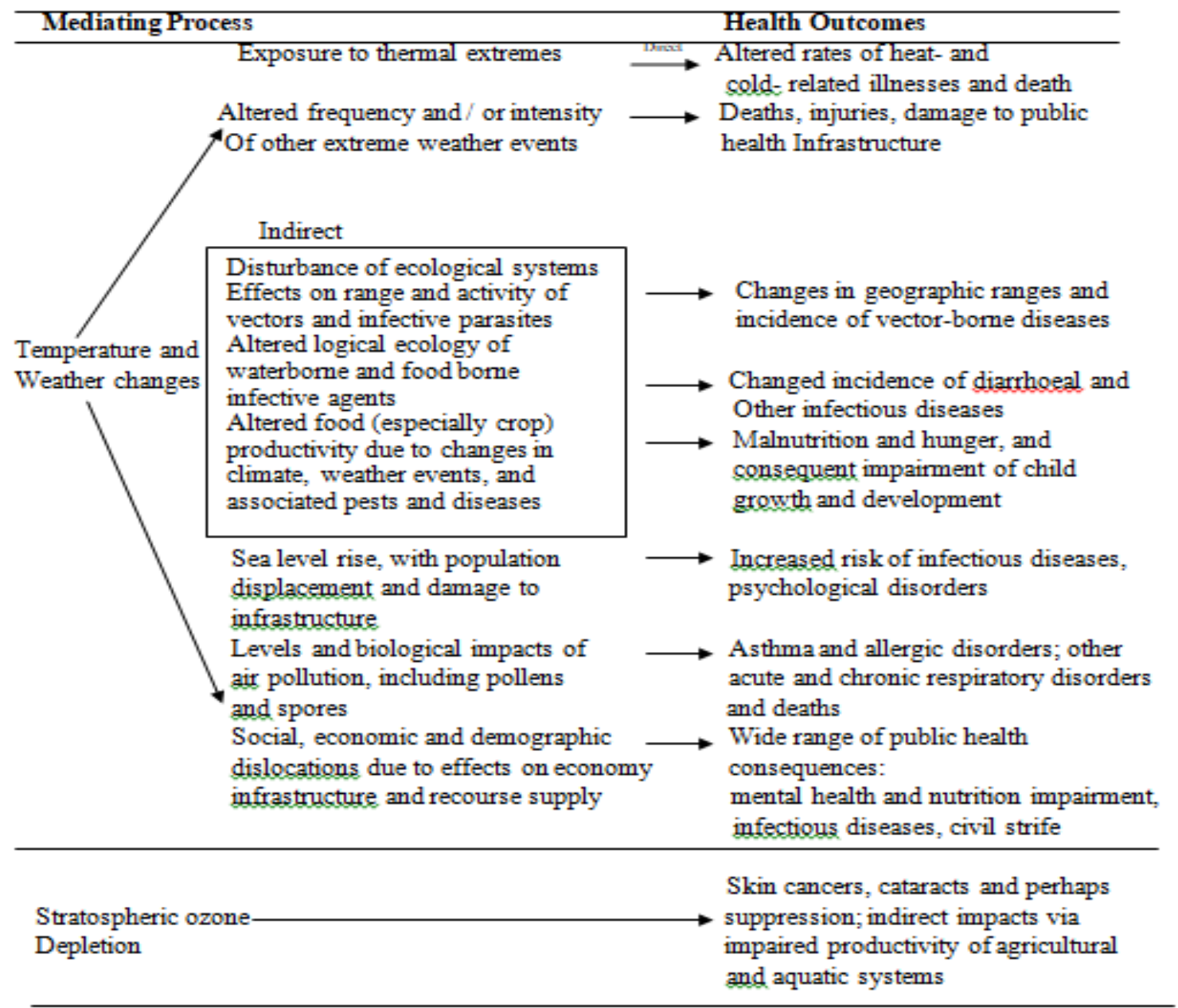

Source: (Hardoy J., Mitlin D.,Satterthwaite D. 2001)).

\section{Discussion}

There is still uncertainty about the possible scale of global warming in the future and its likely direct and indirect effects. But atmosphere concentrations of the most important greenhouse gases (carbon oxides, halocarbons, methane and nitrous oxide) are increasing and the rate of increase for each of these has been particularly rapid since around 1950. There is evidence of an increase in the global average temperature over the last 120 years and many of the warmest years on record have been in the last 15 years. Glaciers in virtually all parts of the world are receding. These are consistent with global warming induced by greenhouse gases released by human activities, but there are uncertainties as to the extent to which the increase in global temperature is the result of human activities and the extent to which it will continue. For instance non-human-induces factors such as volcanic eruptions are also important. Some of the warming trend might be part of a natural variation that may reverse itself. There are uncertainties as to the extent to which increasing carbon dioxide concentrations in the atmosphere will be absorbed by increased plant growth or ocean sinks. But if global warming arising from human-induced release of greenhouse gases does continue, which it certainly will if no action is taken to moderate such emissions, it is likely to create very serious problems for a large number of African countries: (Hardoy J., Mitlin., Satterthwaite D. 2001). 
These Problems can arise from

- The direct effects of changes in temperature (including heat waves) and the changes in weather that this brings, including changes in the hydrological cycle (and thus water supplies) and altered frequency and/or intensity of extreme weather events.

- The indirect effects, as the changes in temperature and the weather induce changes in (among other things) sea levels, ecological systems and air pollution levels, with these ecological changes also having significant effects on, for instance, food production. Table 5.1 illustrates the range of possible health impacts of climate change and also of stratospheric ozone depletion.

Health research on climate change remains a real challenge in Africa due to the lack of investment in these interdisciplinary and multidisciplinary activities of research. Social scientists are questioning their roles about climate change (Grundmann R. 2010; Redclit M. 2009; Yearley S. 2009). A number of African countries have started to pay more attention to climate change by mainstreaming legislations into disasters, for instance South Africa (Pelling M, Holloway A. 2006) as well as Kenya (GoK, 2016). Africa will increasingly be subject to potential confounding impact of air pollution, vector-borne diseases, water-borne diseases (Malaria, Ringworm, Typhoid, Cholera, Amoeba and among others: Diarrhea) and heat-related mortality. Health-related mortality is estimated to rise significantly in Africa (Kalkstein 1. S., Smoyer K., 1993). Southern Africa without sufficient adaptive measures will likely suffer the negative impact on human health. As a future solution, African countries need to adapt themselves to climate change. Adaptation requires public health strategies (disease surveillance and prevention0 and reorganization of health systems.

Recent trend in Health Research on climate change are advocating for public health and environmental strategies and policies to reduce the adverse impact on human health (Verschuren J. 2013; Blackstrand K. 2016). In this context Health Research and public policies should mainstream disaster risk reduction strategies to reduce health vulnerability to climate change. In the last decade, a number of studies have recommended legislations and policies on climate change (Rimmer M. 2011; Richardson J. B. 2012; Reyfuse M. 2012;). Among other studies, many authors have carried out researches on compliance and enforcement in environmental health law, governance and sustainability. (Benidikson J. 2011; Padock L. et al. 2013; ; Van Calster G., 2013; Martin P. et al. 2017). Perspective in climate change law is shifting from international perspective to local perspective (Richardson J. B. 2012; Rayfuse R. 2012 et al.). Many African Counties have domesticated the Kyoto Protocol of 1997 to develop public policies that respond to climate change and adaptation (Carda E. 2010). An author argues that law is about language and that language is the point of commencement of legal reasoning in environmental law, governance and climate change. Importantly, language and legal argumentation and reasoning play a determinant role in effort to achieve sustainability and responses to adverse impact of climate change on human health in Africa (Fisher D. 2013). From Fisher's work law, language, legal reasoning, environmental law, governance, climate change law and international environmental law are linked. The impact of climate change on human health and security raises some element of international social justice.

There is a big gap between Africa and Advanced Industrialized Countries in term of greenhouse gas emissions. Studies raise the concerns of global climate and environmental social justice (Richardson J. B.et al. 2009; Abate R. et al. 2010; Godard O. 2017). Being the least polluters, African counties are more vulnerable in regard to preparedness and climate health related diseases 
African countries are producing less biofuels than China and USA (Le Bouthillieret al 2016; Fitzman et al. 2017; Morgera E. 2017; Farber E. D. 2017). Unfortunately, the continent is the most vulnerable to respond to health impact of climate change. As suggested Health Research studies mitigation and preparedness measures are necessary to lessen the impact of climate change on human health. Among other measures are: environmental governance, environmental law, policies, interdisciplinary and multidisciplinary research (Vatn A. 2015; Galaz V. 2014; Mert A. 2015; martin et al. 2015; Sankar K. 2017). Challenges are still persisting.

\section{Conclusion}

The climate is changing under the human induced activities and natural disasters. The change of climate due to variability of temperatures has impact on health. The impact can be categorize into three: direct effects, indirect effects and postulated effects. Health research on climate attempt to bring holistically climatic scientists and climatic health research scientists and other disciplines together to reduce the vulnerability to climate change. A number of African Countries have mainstreamed legislations on disasters into their Constitution. However, limited funds have been allocated to Health Research on Climate Change in Africa.

\section{References}

[1] Abate S. R., Kronk A. E. (2013). Climate Change and Indigenous People. The search for Legal remedies. Edward Elgar Publishing. Cheltenham, Northhampton. UK. MA. USA

[2] Benidikson J., Boer B.Benjamin H. A., Morrow K.(2011). Environmental Law and Sustainability after Rio. Edward Elgar Publishing. Cheltenham, Northhampton. UK. MA. USA

[3] Blackstrand K., Lovbrand E. (2016). Research Handbook on Climate Governance. Edward Elgar Publishing. Cheltenham, Northhampton. UK. MA. USA

[4] Carda E., Labandeira X. (2010). Climate Change Policies. Prospects. Edward Elgar Publishing. Cheltenham, Northhampton. UK. MA. USA

[5] Demeriit D. (2006). Science Studies, Climate Change, and Prospects for Constructivist Critique. Economy and Society. 35: 453-79.

[6] Demeritt D., Rothman D. S. (1999). Figuring the Costs of Climate Change. An assessment and Critique. Environment and Planning. A 31(3). 389-408.

[7] Farber E. D. A., Peeters M. (2016). Climate Change Law. Edward Elgar Publishing. Cheltenham, Northhampton. UK. MA. USA

[8] Fishser D. (2013). Legal Reasoning in Environmental Law. A study of Structure, Form and Language. Edward Elgar Publishing. Cheltenham, Northhampton. UK. MA. USA

[9] Fitzmanrice M., Tanzi A. PapantoniouA A. 2017). Multilateral Environmental Treaties. Edward Elgar Publishing Cheltenham, Northhampton. UK. MA. USA

[10] Galaz V. (2014). Global Environmental Governance, Technnology and Politics. The Anthropocene Gap. Edward Elgar Publishing Cheltenham, Northhampton. UK. MA. USA

[11] Global Forum for Health Research (2008). Strenghtening the Base: Preparing Health Research for Climate Change. GFHR. Geneva. http://www.who.int/global/climate/index

[12] Godard O. (2017). Gobal Climate Justice. Proposals, Arguments and Justification. Edward Elgar Publishing Cheltenham, Northhampton. UK. MA. USA

[13] Government of Kenya - GoK. (2016). The Disaster Risk Management Bill. 2016. Government Printers. Nairobi. Kenya.

[14] Grundmann R. (2010). Climate Chanege: What Role for Sociology? Current Sociology, Volume 58, Number 5, 897-910. 
[15] Hahn H. C., Yoon K. S. (2012). Responding to Climate Change. Global Experiences and The Korean Perspective. Edward Elgar Publishing Cheltenham, Northhampton. UK. MA. USA

[16] Hardoy J., Mitlin D., Satterthwaite D. (2001). Environmental Problems in an Urbanization World. Earthscan Publications Ltd. London and Sterling. VA.

[17] Hyogo Framework for Action (2003). Post 2015 Framework for Disaster Risk Reduction (HFA2). Report from 2013. Global Forum for Health Research. Geneva.

[18] Intergovernmental Panel on Climate Change (2014). Summary for Policy Makers in climate change 2014. Mitigation of climate change. Cambridge. Cambridge University Press.

[19] Intergovernmental Panel on Climate Change (1995). Climate Change 1995. The Science of climate Change. Houghton JT., Meira F.G., Callander B.A., Harris N., Kattenberg. A., Maskell K. (eds). Cambridge. Cambridge University Press.

[20] Intergovernmental Panel on Climate Change (2000). Special Report on Emission Scenario. Nakicentovich N. (ed). Cambridge. Cambridge University Press.

[21] Intergovernmental Panel on Climate Change (2007). Climate Change. Contribution of Working Group II in the Fourth Assessment Report of the Intergovernmental Panel on Climate Change. (eds). Parry M., Canziani O., Paluukof J., Paul van der Linden, Hanson C. Cambridge. Cambridge University Press.

[22] Intergovernmental Panel on Climate Change. (eds). (2001). Climate Change 2001. The Science of Basis. (eds). Houghton J.T, Ding Y., Griggs D.J et al.. Cambridge. Cambridge University Press.

[23] Kalkstein L. S., Smoyer K (1993). The impact of climate change on human health. Some international implications. Experientia. Vol. 49, pp. 969-979.

[24] Le Bouthillier. Y., Cowie A., Martin P., McLeod Kilmurray H. (2016); The Law and Policy of Biofuels. Edward Elgar Publishing Cheltenham, Northhampton. UK. MA. USA

[25] Martin P., Zhiping U., Tianbao Q., Le Bouthillier Y., Williams A. (2017). Environmental Governance and Sustainability. Edward Elgar Publishing Cheltenham, Northhampton. UK. MA. USA

[26] McMihael A. J. et al. (2004). Comparative Quantification of Health Risks: Global and Regional Burden of Disease due to Selected Major Risk Factors (eds) Ezzati M., Lopez A. D., Roodgers A., Murray C. J. L. Ch. 20, 1543-1649, WHO, Geneva.

[27] McMihael A., Ghiteko A. et al., Akthar R., Carcavallo R., GublberF., Haine A et al. (2001). Human Health in: Climate Change 2001: Impact, Adaptation, and Vulnerability. Contribution of Working Group II to the Third Assessment Report of the the Intergovernmental Panel Conference on Climate Change. McCarty JJ., Canziani OF, Leavy NA, Doreen DJ, White KS (eds). Cambridge, UK, Cambridge University Press 451-485.

[28] Meehl G. A. et al. (2004). Heat Wave in the $21^{\text {st }}$ Century. More Intense. More Frequent. And Longer Lasting. Science, 305, 994.

[29] Mert A. (2015). Environmental Governance through Partnership. Edward Elgar Publishing Cheltenham, Northhampton. UK. MA. USA

[30] Morgera E., Razzaque J. (2017). Biodiversity and Nature Protection Law. Edward Elgar Publishing Cheltenham, Northhampton. UK. MA. USA

[31] Padock L., Du Qun. Kotze L., Marwell D., Zaelke D. (2011). Compliance and Enforcement in Environmental Law. Edward Elgar Publishing Cheltenham, Northhampton. UK. MA. USA

[32] Parry M., Canziani O., Paluukof J., Paul van der Linden, Hanson C. (2007). Climate Change. Contribution of Working Group II in the Fourth Assessment Report of the Intergovernmental Panel on Climate Change (eds). Cambridge. Cambridge University Press.

[33] Pearce D., Cline W.R., Achanta A. N., Fankhausser S., PachauriR. K., Tol R. S., Velinga P. (1996). The Social cost of Climate Change: Greenhouse Damage the Benefits and Control in James P., Bruce, Hoesung Lee and Erik F.Hailes (eds). Climate Change 1995 Economic and Social Dimension of Climate Change. Pp, 179-224, Cambridge, Cambridge University Press.

[34] Peek L. (2006). Transforming the Field of Disaster Research through Training the Next Generation. International Journal of Mass Emergencies and Disasters. Vol.24, No. 3, pp 371-389. 
[35] Pelling M., Hollowya A. (2006). Legislations for mainstreaming disaster rik reduction. Teafund. ISDR.

[36] Redclift M. (2009). The Environment and Carbon Dependence. Current Sociology, Volume 57, Number 3, 369-388.

[37] Reyfuse M., Scott V. S. (2012). International Law in the Era of Climate Change. Edward Elgar Publishing Cheltenham, Northhampton. UK. MA. USA

[38] Richardson J. B. (2012). Local Climate Change Law. Edward Elgar Publishing Cheltenham, Northhampton. UK. MA. USA

[39] Richardson J. B. (2009). Climate Law and Developing Countries. Legal and Policy Challenges for the World Economy Edward Elgar Publishing Cheltenham, Northhampton. UK. MA. USA

[40] Rimmer M. (2011). Intellectual Property and Climate Change. Improving Green Technologies. Edward Elgar Publishing Cheltenham, Northhampton. UK. MA. USA

[41] Robert I. (2008). The Economics of tackling climate change. BMJ, 336 ((7637): 165-6.

[42] Sankar K. M, 2017). Law and Policy for a New Economy. Edward Elgar Publishing Cheltenham, Northhampton. UK. MA. USA

[43] Stackley S., Risbey J., Stone P., Wynne B. (1999). Adjusting to Policy Expectations in Climate Change Science. An interdisciplinary of Flux Adjustment in Couple Atmosphere Ocean General Circulation Model. Climatic Change 43: 413-54.

[44] Stern N. (2007). The Economics of Climate Change. The Stern Review. Cambridge, Cambridge University Press

[45] Terser FC (2006). Potential effects of climate change on malaria transmission in Africa. Lancet.362 (9398): 1792-8.

[46] UNFCCC (2005). United Nations Framework Convention on Climate Change. http://www.unfccc.int

[47] Van der Sluijs, Jjeroen (1997). Anchoring amid Uncertainty on the Management of Uncertainties in Risk Assessment of Anthropogenic Climate Change. Utrecht, Universiteit Utrecht

[48] Vatn A. (2015). Environmental Governance. Instruction, Policies and Actions. Edward Elgar Publishing. Cheltenham, Northhampton. UK. MA. USA

[49] Vatn Calster G., Prevost D. (2013). Research Hanbooh on Evronmental Health and the WTO. Cheltenham, Northhampton. UK. MA. USA

[50] Verschuuren J. (2013). Research Handbook on Climate Change. Adaptation Law. Edward Elgar Publishing. Cheltenham, Northhampton. UK. MA. USA

[51] WHO (2007). Climate Change Health Assessed. http://www.who.int/global/climate/index.

[52] WHO (2007). Climate Change and Health Program Activities. http://www.who.int/global/climate/activities/en/index. html

[53] Yasmin on Schimding (2007). Health in Sustainable Development Planning: the role of indicators. Chapter 7 - Framework for linkage between Health, Environment and Development. WHO., Geneva.

[54] Yearley S. (2009). Sociology and Climte Chang after Kyoto. What Roles for Social Sscience in Understanding Climate Change. Current Sociogy. Vol. 57(3), 389-405

*Corresponding author.

E-mail address: yitambe.andrew@ ku.ac.ke/warutere.peterson@ ku.ac.ke/ ruche.kenneth@ ku.ac.ke 